\title{
EFEKTIFITAS DAN MANFAAT PROGRAM PEMBANGUNAN MASYARAKAT MULIA SEJAHTERA (PMMS) (STUDI DI KABUPATEN ACEH UTARA)
}

\author{
Harjoni Desky \\ Dosen Luar Biasa Jurusan KPI STAIN Malikussaleh Lhokseumawe \\ barjonidesky@yaboo.com,joniku78@yaboo.com
}

\begin{abstract}
The purpose of this study was to determine the effectiveness of implementation of Prosperous Community Development Program and Honor (PMMS) for the alleviation of poverty in the district of North Aceh, and the benefits to be achieved from the PMMS program, whether in accordance with the initial target. This study uses statistical analysis of the test T (Paired Sample T Test) and descriptive analysis. The results showed that the poor in the program PMMS average income increased, in other words PMMS program is able to alleviate poverty by raising income per head of the average member of the PMMS. And in general the benefits of this program are in accordance with the PMMS initial target of launching the program PMMS.
\end{abstract}

Keywords: Effectiveness, Benefits Programs and PMMS

\begin{abstract}
Abstrak
Tujuan penelitian ini adalah mengetabui Efektifitas Pelaksanaan Program Pembangunan Masyarakat Mulia Sejabtera (PMMS) terhadap pengentasan kemiskinan di Kabupaten Aceb Utara, dan manfaat yang ingin dicapai dari Program PMMS ini, apakah telah sesuai dengan sasaran awalnya. Penelitian ini menggunakan analisis statistik yaitu Uji T (Paired Sample T Test) dan deskriptif analisis. Hasil penelitian menunjukkan babwa kelompok miskin dalam program PMMS ratarata mengalami kenaikan pendapatan, dengan kata lain program PMMS ini mampu mengentaskan kemiskinan masyarakat dengan cara meninggikan pendapatan per kepala rata-rata anggota PMMS tersebut. Dan secara umum manfaat dari program PMMS ini telab sesuai dengan target awal dari peluncuran program PMMS ini.
\end{abstract}

Kata Kunci- Efektifitas, Manfaat Program dan PMMS 


\section{Pendahuluan}

Berbagai usaha dilakukan untuk menyelesaikan permasalahan kemiskinan. Usaha penyelesaiannya bisa saja dilaukan dari sektor terkecil kehidupan masyarakat. Keluarga sebagai kelompok sosial terkecil jelas setiap individu dari anggota keluarganya selalu berusaha untuk meningkatkan kesejahteraan dalam pemenuhan setiap kebutuhannya. Tidak jarang mereka merelakan salah satu anggota keluarganya untuk bekerja di tempat yang jauh dari lingkungan keluarganya, dan tidak jarang keluarga merelakan anggota keluarganya untuk bekerja di luar kemampuan profesinya. Hal ini dilakukan, untuk memenuhi apa yang mereka juga butuhkan dalam keluarga.

Kelompok peran intah menengah tidak ketinggalan dalam usaha pengentasan masyarakat sosialnya. Hampir seluruh pemerintah daerah baik provinsi maupun kabupaten dan kota memiliki program yang menekankan pada pengentasan kemiskinan. Tidak terkeculai Negara, sebagai kekuasaan tertinggi dari sistem kedaulatan memiliki tanggung jawab yang besar dalam mensejahterakan rakyatnya. Dapat dipastikan setiap negara menjadikan kemiskinan sebagai musuh besar yang harus dihadapi.

Dimensi lain dari kemiskinan, selain bagian dari problematika kehidupan kemiskinan juga mampu menjadi ranah perdebatan sosial, politik, agama, dan kemiskinan itu sendiri. Kemiskinan mampu melegitimasi nilai-nilai politik, kemiskinan juga mampu menjelma menjadi bagian kehidupan secara theologis. Kemana kemiskin digiring maka hangatlah wilayah kehidupan masyarakat itu.

Kemiskinan merupakan masalah dalam pembangunan yang bersifat multidimensi. Kemiskinan tidak hanya menjadi permasalahan bagi negara berkembang, bahkan negara-negara maju pun mengalami kemiskinan walaupun tidak sebesar negara berkembang. Persoalannya sama namun dimensinya berbeda. Persoalan kemiskinan di negara maju merupakan bagian terkecil dalam komponen masyarakat tetapi bagi negara berkembang persoalan menjadi lebih kompleks karena jumlah penduduk miskin hampir mencapai setengah dari jumlah penduduk. Bahkan ada negara-negara sangat miskin mempunyai jumlah penduduk miskin melebihi dua pertiga dari penduduknya (Booth, A. dan R.M. Sundrum, 1987: 23). 
Parsudi Suparlan (1993:33) menyimbulkan bahwa kemiskinan secara sederhana dapat dilihat sebagai keadaan kekurangan harta dan materi untuk pemenuhan kebutuhan bagi kesejahteraan hidup. Dipihak lain, pengentasan kemiskinan merupakan tujuan pokok dalam pembangunan ekonomi, hal ini senada dengan kajian empiris yang dilakukan Todaro (2000:65) yang menyatakan bahwa pembangunan ekonomi telah digariskan kembali dengan dasar mengurangi atau menghapus kemiskinan, ketimpangan dan pegangguran dalam konteks pertumbuhan ekonomi.

Pembangunan ekonomi di daerah maupun negara pada dasarnya tidak terlepas dari peran serta pemerintah baik dalam menetapkan kebijakan dan peluncuran program-program yang berhubungan dengan masyarakat (Robinson Tarigan, 2002:43). Salah satu Program Pemerintah Aceh yang berkaitan dengan orang miskin dan menarik untuk ditela'ah adalah Program Pembangunan Masyarakat Mulia Sejahtera (PMMS). Program Pembangunan Masyarakat Mulia Sejahtera (PMMS) ini kehadirannya dimaksudkan untuk mengangkat harkat dan martabat kaum dhu'afa/miskin untuk memperoleh kesempatan menikmati kehidupannya yang dilandaskan oleh upaya pembinaan, peningkatan keimanan dan ketaqwaan secara terus menerus, sehingga mampu menjalankan fungsi kekhalifahan dan ta'abudinya kepada Allah SWT.

Program tersebut merupakan program yang berbentuk kelompok (orang-orang dhu'afa/miskin) dan menyeluruh hampir setiap Kabupaten dan Kota di Provinsi Nanggroe Aceh Darussalam memiliki program ini. Dan program ini mempunyai visi terwujudnya masyarakat Aceh yang mulia dan sejahtera, mulia di akhirat dan sejahtera di dunia, yang memiliki ciri-ciri sebagai berikut :

a. Berakhlak mulia yang dilandaskan oleh keimanan dan ketaqwaan yang kokoh kepada Allah SWT, dalam melaksanakan amar mak'ruf nahi mungkar sebagaimana diajarkan dan dicontohkan oleh Rasulullah SAW, para Sahabat dan Para Ulama.

b. Berbudaya, berdisiplin dan bertanggung jawab dalam setiap tindakan yang diridhai Allah SWT.

c. Hidup sejahtera yang dilandasi oleh penguasaan dan pengamalan Iptek, kreatif, inovatif dan mempunyai etos kerja yang tinggi. 
(Pedoman Pelaksanaan Syari'at Islam di Provinsi Nanggroe Aceh Darussalam 2004).

Adapun sasaran program PMMS ini lebih ditekankan kepada perbaikan kesejahteraan masyarakat miskin melalui pembinaan sikap mental kerohanian dan pemberian bantuan modal usaha/kegiatan, jadi ada dua sasaran program ini yaitu : Bidang Pengembangan keagamaan dan Bidang Pemberdayaan Ekonomi.

Program PMMS ini sudah berjalan lebih kurang 3 (tiga) tahun lamanya yaitu sejak tahun 2009. Dan kini banyak hal yang sudah terjadi, khususnya di Kabupaten Aceh Utara. Berdasarkan uraian di atas maka penelitian ini akan mengkaji efektifitas pelaksanaan Program PMMS terhadap pengentasan kemiskinan di Kabupaten Aceh Utara, dan manfaat atau sasaran yang ingin dicapai oleh Program PMMS.

\section{Kemiskinan Negara Berkembang}

Pembahasan mengenai kemiskinan untuk Negara-negara Berkembang yang sering disebut sebagai Negara Dunia Ketiga merupakan kajian menarik dan tidak akan habis-habisnya. Oscar Lewis (1984:76) menyatakan dalam kajian empirisnya bahwa kemiskinan memiliki ciri-ciri sebagai berikut: Kurang/tidak efektifnya partisipasi dan integrasi golongan miskin dalam pranata-pranata utama yang ada dalam masyarakat, hal ini disebabkan antara lain langkanya sumber-sumber daya ekonomi, segregasi dan diskriminasi, ketakutan, kecurigaan/apati pada masyarakat setempat.

Parsudi Suparlan (1993:33) menyimbulkan bahwa kemiskinan secara sederhana dapat dilihat sebagai keadaan kekurangan harta dan materi untuk pemenuhan kebutuhan bagi kesejahteraan hidup. Dipihak lain, pengentasan kemiskinan merupakan tujuan pokok dalam pembangunan ekonomi, hal ini senada dengan kajian empiris yang dilakukan Todaro (2000:65) yang menyatakan bahwa pembangunan ekonomi telah digariskan kembali dengan dasar mengurangi atau menghapus kemiskinan, ketimpangan dan pegangguran dalam konteks pertumbuhan ekonomi. 


\section{Mengukur Kemiskinan}

Berbagai latar belakang masyarakat diyakini tidak pernah terbebas dari diskursus kemiskinan. Walaupun kemiskinan ini secara sederhana dimakna dalam terminologi material, kesejahteraan, dan kebutuhan. Dalam penelitian ini kemiskinan secara material ekonomikal yang menjadi penelitian. Secara ekonomi kemiskinan dapat pula diukur dengan menggunakan berbagai argumentasi dan standard yang digaunakan. Bisa saja dalam sebuah negara bahwa tingkat kemiskinan rakyatnya dapat diukur dari kemampuan memenuhi kebutuhan kesehariannya, atau dapat pula diukur dari tingkat angka produktivitas dari rakyatnya.

Tinggi rendahnya tingkat kemiskinan di suatu negara ataupun daerah tergantung pada dua faktor utama, yakni: 1). Tingkat pendapatan nasional rata-rata/pendapatan per kepala rata-rata, dan 2) Lebar sempitnya kesenjangan dalam distribusi pendapatan. Jelas, bahwa setinggi apapun tingkat pendapatan nasional per kapita suatu negara, selama distribusi pendapatan yang tidak merata, maka tingkat kemiskinan di negara tersebut pasti akan tetap parah. Demikian juga sebaliknya, semerata apapun distribusi pendapatan disuatu negara, jika tingkat pendapatan nasional rata-ratanya tidak mengalami perbaikan, maka kemelaratan juga akan semakin meluas. Adapun yang menjadi ukuran untuk mengukur tingkat kemiskinan pada umumnya digunakan dua cara yaitu: 1). Kemiskinan absolut (absolute poverty)/garis kemiskinan (poverty line), dan 2). Garis kemiskinan internasional (international poverty line).

\section{Solusi Keluar bagi Kemiskinan}

Pembangunan ekonomi di daerah maupun negara pada dasarnya tidak terlepas dari peran serta pemerintah baik dalam menetapkan kebijakan dan peluncuran program-program yang berhubungan dengan masyarakat. Salah satu kebijakan pemerintah tersebut yaitu Pengeluaran Pemerintah. Pengeluaran Pemerintah merupkan paket program ekonomi kerakyatan, hal ini senada dengan teori Wagner dan Keynes (Robinson Tarigan, 2002:43). W.W. Rostow dan Musgrave menghubungkan pengeluaran pemerintah dengan tahap-tahap pembangunan ekonomi, tahap 
awal penyediaan prasarana, tahap menengah Investasi Pemerintah tetap diperlukan untuk memacu pertumbuhan ekonomi agar dapat lepas landas.

Todaro (2000:54) dalam teorinya menambahkan bahwa akumulasi modal akan terjadi apabila sebagian dari pendapatan ditabung dan diinvestasikan dengan tujuan memperbesar output dan pendapatan di kemudian hari. Pabrik baru, mesin dan peralatan meningkatkan stok modal secara fisik dan memungkinkan tercapainya peningkatkan output. Investasi produksi ini harus juga dilengkapi dengan investasi yang diarahkan pada kesempurnaan infrastruktur sosial dan ekonomi, seperti : jalan, air dan sanitasi, komunikasi, penyuluhan dan sebagainya, guna menunjang aktivitas perekonomian secara terpadu. Sebagai contoh, investasi seorang petani sayuran dengan membeli traktor baru dapat meningkatkan produksinya, namun tanpa fasilitas angkutan yang memadai gunanya mengangkut tambahan produksi tersebut ke pasar, maka investasi tersebut tidak akan menambah produksi pangan (Todaro, 2000:16)

\section{Metode Penelitian}

Penelitian ini dilakukan di Kabupaten Aceh Utara Provinsi Nanggroe Aceh Darussalam. Sementara yang menjadi sampel dalam penelitian ini adalah 10 (sepuluh) kelompok PMMS dari 74 Kelompok yang ada dan 30 orang anggota dari 740 orang keseluruhan melalui Simple Random Sample dan Multiple Stage Sample yaitu teknik yang digunakan untuk pengambianl sampel. (M. Nazir, 1988:45).

Data yang digunakan dalam penelitian ini adalah data primer dan data sekunder, untuk memperoleh data primer dengan cara survay dan wawancara sedangkan untuk data sekunder yang merupakan data time serie dari tahun 2009 sampai dengan 2011 memperolehnya dengan cara mengumpulkan dari berbagai instansi atau lembaga terkait antara lain; BPS, Data dari Dinas Syari'at Islam Kabupaten Aceh Utara, Bappeda dan lain-lainnya. Kemudian datadata yang diperoleh baik data primer maupun sekunder estimasi dilakukan dengan menggunakan teknik analisis Uji t/Uji beda. 
Untuk menjawab rumusan masalah yang pertama, maka digunakan analisis statistik yaitu Uji $\mathrm{T}$ untuk Dua Sampel yang Berpasangan (Paired Sample T Test) Uji T Dua Sampel yang Berpasangan diartikan sebagai sebuah sampel dengan subyek yang sama namun mengalami dua perlakuan atau pengukuran yang berbeda (Singgih Santoso, 2003:51). Sedangkan untuk menjawab rumusan masalah yang kedua digunakan deskriptif analisis.

Kumpulan data-data sekunder maupun primer sejauh mungkin akan ditampilkan untuk mendukung analisis yang disampaikan. Setiap perkembangan data yang diperoleh akan ditampilkan dalam laporan penelitian. Dengan demikian, kegiatan analisis data sudah mulai dilakukan pada saat-saat awal pengumpulan data lapangan dan seterusnya sampai dengan selesainya pengumpulan data lapangan. Data yang telah dikumpulkan di atur secara beruturan, diorganisasikan ke dalam suatu pola, dikategorikan dan diuraikan ke dalam satuan uraian dasar sehingga ditemukan tema dan dapat dirumuskan hipotesis seperti yang disarankan oleh data.

Selanjutnya data-data tersebut akan dibandingkan dan diintepretasikan. Perbandingan data tersebut gunanya untuk menemukan data-data yang kurang valid, terhadap hal yang demikian data tersebut akan direduksikan. Sementara keseluruhan data yang dimiliki akan dicoba interpretasikan dengan sebaik mungkin, dengan harapan dapat memahami dengan sebaik-baiknya data yang diperoleh, sehingga pada gilirannya dapat memahami dan menemukan jawaban pula terhadap persoalan yang diteliti. Data secara keseluruhannya akan dituangkan dalam laporan penelitian dalam bentuk naratif-teoritis, artinya semua data yang dianalisis telah diberikan makna teoritiknya.

\section{Analisis}

\section{Gambaran Umum Daerab Penelitian}

Kabupaten Aceh Utara terletak pada garis $96.52^{\circ} .00-97^{\circ} .31 .00$ Bujur Timur dan 04.46 $00-05^{\circ} .00 .40$ Lintang Utara. Dengan luas daerah 3.296.86 $\mathrm{Km}^{2}$. Adapun batas-batas daerah kabupaten tersebut adalah sebagai berikut : 
Tabel 1

Batas-batas Wilayah Kabupaten Aceh Utara

\begin{tabular}{ll}
\hline Batas & Kabupaten aceh Utara \\
\hline Sebelah Utara & Kota Lhokseumawe dan Selat Malaka \\
Sebelah Selatan & Kabupaten Aceh Tengah \\
Sebelah Timur & Kabupaten Aceh Timur \\
Sebelah Barat & Kabupaten Biereun \\
\hline
\end{tabular}

Sumber : Aceh Utara dalam Angka 2012

Kabupaten Aceh Utara ini beriklim tropis, kemarau berlangsung antara bulan Februari sampai Agustus. Sedangkan musim hujan, antara September sampai Januari. Suhu dimusim kemarau rata-rata 32,8 OC dan pada musim hujan rata-rata 28 OC. Kabupaten ini juga mempunyai beberapa gunung dan sungai yang bermuara ke Selat Malaka, yaitu : Gunung Panyang, Gunung Ujong, Gunung Kareueng, Gunung Batee, Sungai Krueng Tuan, Kruang Pase, Krueng Keureuto, dan Krueng Jambo Aye. Secara geografis 5\% dari jumlah gambong/kelurahan terletak dikawasan pantai, $83 \%$ dataran rendah, $6 \%$ merupakan kawasan lembah dan $6 \%$ merupakan kawasan berbukit. (BPS, Aceh Utara Dalam Angka 2012).

Menurut keadaan topografis, 89\% gampong (desa) merupakan daerah daerah datar, dan 11\% berbukit. Menurut klasifikasi perkembangan gampong yang terdapat dalam kabupaten ini termasuk dalam katagori desa swakarya. Sedangkan dilihat dari kedalaman efektif tanah maka 78,67\% dari luas wilayah mempunyai kedalaman efektif $90 \mathrm{~cm}, 10,70 \%$ dengan kedalaman efektif 60-90 cm dan 10,63\% dengan kedalaman efektif 30-60 cm (BPS, Aceh Utara dalam Angka 2012).

Secara administrasi Kabupaten Aceh Utara ibu kotanya Lhoksukon, dengan 27 Kecamatan, 56 kemukiman, 2 kelurahan dan 850 desa. Dimana kecamatan yang paling luas wilayahnya adalah Kecamatan Paya Bakong sekitar 418,32 $\mathrm{Km}^{2}$ dan kecamatan terkecil yaitu Kecamatan Syamtalira Aron dengan luas wilayahnya $28,13 \mathrm{Km}^{2}$ (BPS, Aceh Utara dalam Angka 2012) Jumlah penduduk di Kabupaten ini dihuni oleh 496.021 jiwa penduduk. Jumlah ini mengalami kenaikan sebesar 4,58\%. 
Sehubungan dengan keadaan geografis kabupaten ini, maka potensi sumber daya alam dan lingkungan yang ada di kabupaten ini sangat beragam dan tersebar di setiap kecamatan dan gampong/ kelurahan, potensi tersebut terdapat pada sektor pertanian dalam arti luas dan sektor pertambangan (minyak, gas alam dan lain-lain). Dari sektor pertanian, kabupaten ini menghasilkan padi, jagung, kedelai, sayuran, pisang, dan buah-buahan seperti durian, rambutan, langsat, semangka, mangga dan jeruk. Dari sektor perkebunan, Kabupaten Aceh Utara menghasilkan coklat, pinang, kelapa sawit, lada, kunyit dan jahe. Sedangkan dari sektor pertambangan Kabupaten Aceh Utara menghasilkan minyak, gas alam, batu kapur, batu gamping, supit, truss, groint, pasir dan kerikil. Gas alam dan kondesate diusahakan oleh Exxon Mobil sedangkan pengolahannya/pencairannya dilaksanakan PT. Arun NGL Co. Dan pemasaran oleh Pertamina.

Flora yang terdapat di Aceh Utara terdiri dari berbagai jenis tumbuhan kayu antara lain kayu merbau, damar, damar laut, semantok, meranti, cemara, kayu bakau, rotan dan sebagainya. Semua tumbuhan hidup subur dikawasan hutan Aceh Utara yang merupakan kekayaan dan potensi yang dapat mendukung pembangunan ekonomi jika mampu dikelola dengan baik dengan menjaga kelestarian alam dan lingkungan. Sedangkan Fauna yang terdapat di Aceh Utara, seperti gajah, harimau, badak, rusa, kijang, orang utan dan burung-burung yang sangat menakjubkan (Dinas Informasi dan Komunikasi, Aceh Utara Data, Informasi dan Promosi Daerah, 2012).

Efektifitas Pelaksanaan PMMS terhadap pengentasan kemiskinan di Kabupaten Aceh Utara

Paket Program Pembangunan Masyarakat Mulia Sejahtera (PMMS) yang dilaksanakan oleh Pemerintah Provinsi Nangroe Aceh Darussalam (NAD) dalam hal ini Dinas Syari'at Islam Provinsi sebagai Penanggung Jawab secara umum. Sedangkan untuk daerah Kabupaten/Kota Dinas Syari'at Islam Kabupaten/Kota sebagai penanggung jawabnya. Program ini merupakan upaya pemerataan hasil pembangunan di daerah dan upaya untuk mempertajam pelaksanaan Visi dan Misi Pembangunan Provinsi maupun masingmasing Kabupaten/Kota. 
Program PMMS ini diluncurkan guna mengikis kemiskinan dan mengangkat kaum dhu'afa yang selama ini termarjinalkan dari buah pembangunan maupun objek pembangunan itu sendiri. Diharapkan dengan paket bantuan yang sedikit (Rp.35.000.000,-) kelompok masyarakat dhua'fa/miskin mampu memberdayakan diri baik itu bagi peningkatan kegiatan keagamaan maupun modal usaha mereka dimana nantinya keuntungan usaha tersebut dapat dikembangkan untuk membentuk/menambah personal kelompok masyarakat dhu'afa yang baru. PMMS ini juga merupakan bagian dari Pengeluaran Pemerintah. Dimana Pengeluaran Pemerintah secara teori merupakan paket program ekonomi kerakyatan sebagai investasi bagi rakyat guna menumbuh kembangkan daya cipta masyarakat dhu'afa dalam berusaha, hal ini senada dengan teori Wagner dan Keynes (Robinson Tarigan, 2002:43).

Pemberian modal bagi kelompok masyarakat dhu'afa/ miskin untuk tahun 2010/2011 sebesar Rp. 35.000.000,- dengan dua sasaran program yaitu: Bidang Pengembangan Keagamaan sebesar Rp.5.000.000,- dan Bidang Pemberdayaan Ekonomi sebesar Rp.30.000.000,-. Perkelompoknya beranggotakan minimal 10 (sepuluh) orang, ini besarnya bantuan untuk tahun 2011 dengan demikian perorangnya mendapat bantuan Rp.3.000.000,-. Sedangkan untuk tahun 2009/2010 bantuan yang diberikan sebesar Rp.50.000.000,- dengan pembagian untuk bidang pengembangan keagamaan sebesar Rp.10.000.000,- dan bidang pemberdayaan ekonomi sebesar Rp.40.000.000,- dengan demikian perorangnya mendapat bantuan Rp.4.000.000,-

Biasanya bantuan untuk pengembangan keagamaan dimanfaatkan untuk pengembangan Syiar Islam di Dayah (Pesantren)/ Balai Pengajian pada gampong/desa kelompok PMMS itu, baik itu kegiatan keagamaan, pengajian, perehapan balai pengajian, honor guru maupun pembelian kitab dan sebagainya. Sedangkan bantuan untuk pemberdayaan ekonomi kerakyatan biasanya diperuntukan sebagai modal usaha peternakan seperti beli lembu, kerbau, kambing guna dikembang biakan, dan sebagian lagi untuk modal usaha seperti jualan, buka koperasi, modal tambak ikan/udang maupun usaha perkebunan sesuai dengan skill dan keinginan para peserta kelompok PMMS tersebut. 
Ada beberapa hal yang hendaknya harus dipenahi dalam pemberian bantuan PMMS ini yaitu hendaknya bantuan PMMS yang diperikan ditunjang dengan tim teknis/penyuluhan dari dinas terkait, misalnya dari Dinas Pertenakan. Sehingga nantinya para anggota PMMS tersebut menjadi pertenak yang handal minimal di daerahnya, karena didukung dengan adanya sistem peternak yang baik, demikian juga pada bidang usaha lainnya. Untuk Kabupaten Aceh Utara kelompok PMMS dalam tahun 2009 terdiri dari 74 Kelompok yang diketuai oleh seorang ketua kelompok yang berasal dari Pimpinan Dayah/pasentren atau Balai Pengajian, hal ini sesuai dengan upaya pemerintah untuk mengimplementasikan Syari'at Islam ditengah-tengah masyarakat dimulai dari pemuka agama/ tokoh di desanya.

Secara umum dana bantuan yang diberikan oleh pemerintah tersebut tidak diminta untuk dikembalikan kecuali terjadi kesalahan penggunaan dana atau kecurangan, penggantinya setiap semester tiap kelompok diharuskan membuat laporan yang ditujukan ke Dinas Syari'at Islam Kabupaten/Kota. Kemudian Dinas Syari'at Islam Kabupaten/Kota juga membentuk Tim Monotoring yang terdiri dari Dinas Syari'at Islam, Bappeda, Depag, MPU Kabupaten/Kota untuk melakukan cross cek dilapangan setiap tahunnya secara terjadwal. Pengecekan dilapangan juga akan melihat usaha apa yang dijadikan sebagai pemanfaatan modal dari paket Program PMMS ini, disamping juga melihat perkembangan kelompok PMMS tersebut, juga menerima masukan maupun saran dari kelompok PMMS, sehingga terjadi sherring yang nantinya akan dibawa ke musyawarah tim monotoring untuk ditindak lanjuti.

Sebelum pemberian paket bantuan PMMS ini, tim monotoring sebelumnya melakukan pengecekan dilapangan untuk menyahuti proposal awal dari kandidat kelompok yang akan memperoleh bantuan PMMS ini, setiap kelompok PMMS hendaknya terdiri dari 10 (sepuluh) anggota dari orang-orang dhu'afa/miskin di gampong tersebut, yang juga memiliki ketaatan dalam melaksanakan Syari'at Islam secara kaffah.

Sebagai contoh dapat dilihat beberapa kelompok PMMS dari 74 kelompok PMMS yang ada, pada tabel 2 sebagai berikut; 
Tabel 2

Nama-nama Kelompok PMMS Aceh Utara 2009

\begin{tabular}{|c|c|c|c|c|}
\hline No & Kecamatan & Gampong & Nama Kelompok & Ketua \\
\hline 1 & 2 & 3 & 4 & 5 \\
\hline \multirow[t]{3}{*}{1} & Sawang & Gp.Paya Rabo & PMMS Al-Ikhlas & Tgk.M.Nasir \\
\hline & & Gp.Blang Manyak & PMMS Baitul Ikhlas & Tgk.Mustafa Is \\
\hline & & Gp.Blang Teurakan & PMMS Babussa'adah & Tgk.M.Nasir \\
\hline \multirow[t]{4}{*}{2} & Nisam & Gp.Teungoh & PMMS Nasrul Muta'alimin & Tgk.Armansyah AR \\
\hline & & Gp.Mns Beunot & PMMS Babul Huda & Tgk.Husnon \\
\hline & & Gp.Sangkelan & PMMS Miftahussa'adah & Tgk.H.Syibran \\
\hline & & Gp.Paloh Mampre & PMMS Darul Ulum & Tgk.A.Rahman S \\
\hline \multirow[t]{2}{*}{3} & M. Batu & Gp.Cot Usi & PMMS Raudhatul M & Tgk. Armia M Ali \\
\hline & & Gp.Pinto Makmur & PMMS Nurul Hikmah & Tgk.M.Daud \\
\hline \multirow[t]{4}{*}{4} & Dewantara & Gp.Bangka Jaya & PMMS Darul Falah & Tgk.Jalaluddin I \\
\hline & & Gp..Ulee Pulo & PMMS Raudatussa'adah & Tgk.Jamaluddin \\
\hline & & Gp.Sulu Barat & PMMS Darul Qira'ah & Tgk.Ridwan Yunus \\
\hline & & Gp.Lancang Barat & PMMS Ashabulyamin & Tgk.Mahmudan HS \\
\hline \multirow[t]{4}{*}{5} & Kutamakmur & Gp.Cot Meureubo & PMMS Babul Huda & Tgk.M.Nasir \\
\hline & & Gp.Lhok Jok & PMMS Matlabul Ilmi & Tgk.Ibnu Hasan \\
\hline & & Gp.Cempedak & PMMS Ma'had U & Tgk.Baharuddin \\
\hline & S.Kramat & Gp.Ceumecot & PMMS Darul Ilmi & Tgk.M.Amin \\
\hline \multirow[t]{3}{*}{6} & & Gp.Raleu & PMMS Darul Athfal & Tgk.Mayeddin \\
\hline & & Gp.Ie Trek I & PMMS Bustanul M & Tgk.Muslim \\
\hline & S. Bayu & Gp.Paya Tengoh & PMMS Tgk.Batee Timoh & Tgk.M.Hanfiah \\
\hline 7 & Samudera & Gp.Beunot & PMMS Al-Huda & Tgk. Iskandar \\
\hline \multirow[t]{6}{*}{8} & & Gp.Teupin Beulangan & PMMS Majmul Fata & Tgk.Herwin Ilyas \\
\hline & & Gp.Ampeh Mulieng & PMMS Nurul Huda & Tgk.Ismail M \\
\hline & & Gp.Blang Nibong & PMMS Uswatun $\mathrm{H}$ & Tgk.Syarifuddin \\
\hline & & Gp.Keude Geudong & PMMS Darussyari'ah & Tgk.Ismail Daud \\
\hline & & Gp.Blang Kabu & PMMS Darul Muttaqin & Tgk.Usman \\
\hline & & Gp.Teungoh & PMMS Miftahul Huda & Tgk.Zulkifli Affan \\
\hline
\end{tabular}

Sumber : SK Kelompok PMMS 2010 dari Dinas Syari’at Islam Kab. Aceh Utara

Manfaat dari program Pembangunan Masyarakat Mulia Sejahtera (PMMS) bagi pengentasan kemiskinan masyarakat khususnya untuk mengangkat pendapatan masyarakat dhua'fa yang menjadi kelompok PMMS ini, maka dapat dilihat pengembangannya pada tabel 3, yang berisikan 2 tahun pendapatan per kepala ratarata sebelum adanya program PMMS dan 2 tahun setelah PMMS, sebagai berikut; 
Tabel 3

Pendapatan Per Kepala Rata-rata Anggota PMMS sebelum dan Sesudah dalam 2 Tahun Masing-masing

\begin{tabular}{llllll}
\hline \multirow{2}{*}{ No } & \multirow{2}{*}{ Bulan } & \multicolumn{4}{c}{$\begin{array}{c}\text { Pendapatan PerKepala Rata-rata } \\
\text { Sebelum }\end{array}$} \\
& & Thn 2008 & Thn 2009 & Thn 2010 & Thn 2011 \\
\hline 1 & Januari & $300.000,-$ & $300.000,-$ & $315.000,-$ & $381.000,-$ \\
2 & Februari & $300.500,-$ & $300.020,-$ & $315.000,-$ & $383.000,-$ \\
3 & Maret & $301.000,-$ & $302.000,-$ & $323.000,-$ & $400.000,-$ \\
4 & April & $302.000,-$ & $304.000,-$ & $330.000,-$ & $500.000,-$ \\
5 & Mei & $303.000,-$ & $305.000,-$ & $345.000,-$ & $520.000,-$ \\
6 & Juni & $300.000,-$ & $300.000,-$ & $350.000,-$ & $540.000,-$ \\
7 & July & $307.000,-$ & $308.000,-$ & $355.000,-$ & $560.000,-$ \\
8 & Agustus & $304.000,-$ & $307.000,-$ & $350.000,-$ & $566.000,-$ \\
9 & September & $300.000,-$ & $302.000,-$ & $360.000,-$ & $575.000,-$ \\
10 & Oktober & $300.000,-$ & $300.000,-$ & $370.000,-$ & $600.000,-$ \\
11 & November & $301.000,-$ & $303.000,-$ & $375.000,-$ & $478.000,-$ \\
12 & Desember & $300.000,-$ & $302.000,-$ & $370.000,-$ & $490.000,-$ \\
\hline
\end{tabular}

Sumber: Hasil Wawancara dengan 30 anggota PMMS yang diolah/ diambil menjadi pendapatan rata-rata mereka perbulan

Pada tabel 3 dapat dilihat bahwa pendapatan per kepala rata-rata peserta kelompok PMMS ini mengalami peningkatan antara sebelum adanya program PMMS dengan sesudah program PMMS. Perbedaan ini akan di uji dengan uji t/uji beda.

\section{Komparasi Pendapatan Per Kepala Rata-rata Anggota Sebelum dan Sesudah PMMS}

Sebagaimana penjelasan sebelumnya bahwa kemiskinan itu dapat diketahui dan diukur dari pendapatan per kepala rata-rata, oleh karena itu maka yang menjadi objek pengujian dalam penelitian ini adalah pendapatan per kepala rata-rata yang dibedakan sebelum adanya program PMMS (2008) dibandingkan dengan sesudah adanya program PMMS (2011) bagi peningkatan pendapatan per kepala rata-ratanya atau bagi pengentasan kemiskinan anggota kelompok PMMS yang dhu'afah/miskin.

Adapun uji yang digunakan untuk menjawab penelitian ini adalah uji t untuk dua sampel yang berpasangan (paired) atau paired 
sample t test dibantu dengan bantuan SPSS Versi 11,5. (Singgih Santoso, 2003:43).

Tabel 4

Pendapatan Per Kepala Rata-rata Anggota PMMS

Tahun 2008 dan Tahun 2011

\begin{tabular}{clcc}
\hline No & Bulan & $\begin{array}{c}\text { Pendapatan Per Kepala Rata-rata } \\
\text { Sebelum PMMS } \\
\text { Thn 2008 }\end{array}$ & $\begin{array}{c}\text { Sesudah PMMS } \\
\text { Thn 2011 }\end{array}$ \\
\hline 1 & Januari & $300.000,-$ & $381.000,-$ \\
2 & Februari & $300.020,-$ & $383.000,-$ \\
3 & Maret & $302.000,-$ & $400.000,-$ \\
4 & April & $304.000,-$ & $500.000,-$ \\
5 & Mei & $305.000,-$ & $520.000,-$ \\
6 & Juni & $300.000,-$ & $540.000,-$ \\
7 & July & $308.000,-$ & $560.000,-$ \\
8 & Agustus & $307.000,-$ & $566.000,-$ \\
9 & September & $302.000,-$ & $575.000,-$ \\
10 & Oktober & $300.000,-$ & $600.000,-$ \\
11 & November & $303.000,-$ & $478.000,-$ \\
12 & Desember & $302.000,-$ & $490.000,-$ \\
\hline
\end{tabular}

Sumber: Hasil Wawancara dengan 30 anggota PMMS yang diolah/ diambil menjadi pendapatan rata-rata mereka perbulan

Dari tabel 4 dapat dilihat pada garis 1, bahwa pendapatan per kepala rata-rata kelompok PMMS untuk 10 sampel kelompok dan 30 populasi dari 740 orang secara keseluruhan mempunyai pendapatan per kepala rata-rata sebesar Rp.300.000,-. Setelah dilaksanakan program PMMS ini mengalami peningkatan pendapatan menjadi Rp.381.000,-. Demikian juga untuk data yang lain.

Dari hasil pengujian yaitu uji t dengan bantuan SPSS maka di dapat hasilnya sebagai berikut:

Tabel 5

Paired Samples Statistics

\begin{tabular}{lllll}
\hline & Mean & N & Std. Deviation & Std. Error Mean \\
\hline Pair SEBELUM & 302751.67 & 12 & 2765.705 & 798.390 \\
1 SESUDAH & 499416.67 & 12 & 76283.512 & 22021.153 \\
\hline
\end{tabular}

Sumber: Lampiran output SPSS 


\section{Output Bagian Pertama}

Bagian pertama output ini terlihat ringkasan statistik dari kedua sampel. Untuk pendapatan per kepala rata-rata masyarakat dhu'afa sebelum pelaksanaan program PMMS yaitu selama 12 bulan, Masyarakat Dhu'afah tersebut mempunyai pendapatan per kepala rata-rata sebesar Rp. 302.751,67 per bulannya. Sedangkan setelah pelaksanakan program PMMS masyarakat yang menjadi anggota kelompok PMMS tersebut mempunyai pendapatan per kepala ratarata sebesar Rp. 499.416,67 perbulannya.

Hal ini senada dengan teori yang dikemukan oleh oleh Todaro (2000:34) yang menyatakan bahwa akumulasi modal yang diinvestasikan nantinya akan memperbesar output dan pendapatan di kemudian hari. Herrick dan Kindleberger (1998:26) juga menegaskan bahwa pembentukan modal pada akhirnya berdampak pada terciptanya output yang lebih besar yang dapat memberikan surplus untuk investasi lebih lanjut dalam kapasitas produksi.

Tabel 6

Paired Samples Correlations

\begin{tabular}{lccc}
\hline & $\mathrm{N}$ & Correlation & Sig. \\
\hline Pair SEBELUM \& 1 SESUDAH & 12 & .398 & .200 \\
\hline
\end{tabular}

Sumber: Lampiran output SPSS

\section{Output Bagian Kedua}

Bagian kedua output adalah hasil korelasi antara kedua variabel, yang menghasilkan angka 0,398 dengan nilai probabilitas jauh dibawah 0,05 (lihat nilai signifikansi output yang 0,200). Hal ini menyatakan bahwa korelasi antara pendapatan per kepala rata-rata sebelum dan sesudah pelaksanaan/menjadi anggota PMMS adalah sangat erat dan benar-benar berhubungan secara nyata. Dengan kata lain program PMMS ini memiliki hubungan/korelasi yang nyata terhadap pengentasan kemiskinan yang ditandai dengan kenaikan pendapatn per kepala rata-rata.

Hasil dari pengujian penelitian ini/ujian korelasi. Sesuai dengan teori yang dikemukan oleh kaum Neo-Klasik yang menyebutkan bahwa pertumbuhan ekonomi sebagai proses pengentasan 
kemiskinan dipengaruhi oleh faktor-faktor sebagai berikut: 1). Sumber daya alam, 2). Tenaga Kerja, 3) Akumulasi modal dan pengembangannya, dan 4). Tingkat kemajuan teknologi. (Arsyad, 1992:46).

Tabel 7

Paired Samples Test

\begin{tabular}{|c|c|c|c|c|c|c|}
\hline & \multicolumn{2}{|r|}{ Paired } & \multicolumn{3}{|l|}{ Differences } & \multirow{3}{*}{$\mathrm{T}$} \\
\hline & \multirow[b]{2}{*}{ Mean } & \multirow[b]{2}{*}{$\begin{array}{c}\text { Std. } \\
\text { Deviaton }\end{array}$} & \multirow[b]{2}{*}{$\begin{array}{l}\text { Std. Error } \\
\text { Mean }\end{array}$} & \multicolumn{2}{|c|}{$\begin{array}{l}\text { 95\% Confidence Internal of } \\
\text { The Difference }\end{array}$} & \\
\hline & & & & Lower & Upper & \\
\hline $\begin{array}{l}\text { Pair SEBELUM- } \\
1 \text { SESUDAH }\end{array}$ & -196665.00 & 75226.454 & 21716.007 & -244461.61 & -148868.39 & -9.056 \\
\hline
\end{tabular}

Sumber: Lampiran output SPSS

\section{Output Bagian Ketiga (Paired Sample Test)}

a. Hipotesis

Hipotesis untuk kasus ini adalah sebagai berikut :

$\mathrm{H}_{\mathrm{o}}=$ Kedua rata-rata populasi adalah identik (rata-rata populasi berat sebelum pelaksanaan program PMMS dan sesudah menjadi anggota PMMS adalah tidak berbeda secara nyata)

$\mathrm{H}_{1}=$ Kedua rata-rata populasi adalah tidak identik (rata-rata populasi berat sebelum pelaksanaan program PMMS dan sesudah menjadi anggota PMMS adalah memang berbeda nyata)

b. Pengambilan Keputusan

Dasar Pengambilan Keputusan :

1). Berdasakan perbandingan t hitung dengan t tabel :

a). Jika statistik hitung (angka t output) > Statistik tabel (tabel $\mathrm{t}$ ), $\mathrm{H}_{0}$ ditolak.

b). Sedangkan jika statistik hitung (angka t output) < Statistik tabel (tabel t), $\mathrm{H}_{0}$ diterima.

Setelah dilihat ternyata thitung dari output adalah -9,056 Sedangkan statistik tabel bisa dihitung pada tabel t, 
dengan cara:

a). Tingkat signifikan (o) adalah 5\%

b). Dengan df (degree of freedom) atau derajat kebebasan dicari dengan rumus : jumlah data -1 atau $12-1=11$

c). Uji dilakukan dengan Dua Sisi karena akan diketahui apakah rata-rata SEBELUM sama dengan SESUDAH ataukah tidak. Jadi bisa lebih besar atau lebih kecil, karenanya dipakai uji dua sisi. Perlunya Uji dua sisi bisa diketahui pula dari output SPSS yang menyebutkan adanya two tailed test.

2). Dari tabel t, didapat angka 2,2010

Oleh karena t hitung terletak di luar daerah $\mathrm{H}_{0}$ ditolak, maka dapat disimpulkan bahwa program PMMS bagi Masyarakat Dhu'afa/anggota PMMS tersebut berpengaruh efektif/nyata terhadap peningkatan pada pendapatan per kepala rata-rata anggota kelompok PMMS di Kabupaten Aceh Utara dari 30 sampel yang diambel dengan 12 bulan pendapatan per kepala yang diuji. Dengan kata lain program PMMS ini salah satu usaha/program pengentasan kemiskinan bagi masyarakat Kabupaten Aceh Utara.

Hasil ini sesuai dengan teori yang dikemukan oleh HarrodDomar bahwa pembentukan modal sangat penting sebagai usaha untuk menciptakan pertumbuhan ekonomi di suatu daerah, bila pertumbuhan ekonomi dapat terwujud maka secara berangsurangsur kemiskinan juga akan hilang. Senada dengan itu David Ricardo menambahkan bahwa untuk mendukung pertumbuhan ekonomi suatu daerah, investasi pertanian dan perternakan juga memiliki peran yang tak kalah pentingnya terutama bagi negaranegara yang berkembang atau daerah pertanian (M.L.Jhingan 2002:67).

\section{Manfaat dan Sasaran Program PMMS}

Manfaat program PMMS sebagaimana telah diuraian sebelumnya tidak lain adalah salah satu usaha dalam mengangkat harkat dan martabat kaum dhu'afa/miskin dengan upaya pembinaan, 
peningkatan keimanan dan ketaqwaan secara terus menerus. Program ini menjadi salah usaha dalam pengentasan kemiskinan bagi masyarakat khususnya masyarakat Kabupaten Aceh Utara dimana diharapkan masyarakat Aceh Utara mendapatkan kemulian dan kesejahteraan, mulia di akhirat dan sejahtera di dunia. Sedangkan sasaran dari program PMMS ini adalah kaum dhu'afah/miskin yang layak untuk dibantu. Program ini lebih ditekankan kepada perbaikan kesejahteraan masyarakat miskin melalui pembinaan sikap mental kerohanian dan pemberian bantuan modal usaha/ kegiatan, dengan sasaran program yaitu, bidang pengembangan keagamaan dan bidang pemberdayaan ekonomi.

Ternyata ada beberapa kejanggalan yang terdapat di lapangan yaitu adanya sebagian kelompok PMMS/ketua kelompok PMMS yang merekrut anggota kelompoknya dari kalangan saudara sendiri bukan mengangkat kaum dhu'afa sebagai anggota. Sehingga program PMMS ini sasarannya agak melenceng menjadi paket program keluarga. Dan sebagian lagi anggotanya orang tua santri/ anak didiknya di pengajian yang kadangkala bukan kaum dhu'afa. (Hasil Survai dan wawancara, tgl:22 - 02 - 2012).

Dilapangan juga ditemukan sebagian dari usaha kelompok PMMS ini tidak mengalami kemajuan yang berarti, misalnya usaha ternak lembu karena tidak adanya tim teknis/tim dari dinas peternakan dalam pemberian pengarahan/masukan bagaimana sistem berternak yang baik, demikian juga usaha koperasi yang dibentuk oleh kelompok PMMS tidak mengalami kemajuan karena kurang mengertinya mereka bagaiman manajemen koperasi yang baik, dan usaha-usaha lainnya.

Salah satu kendala yang dihadapi dilapangan adalah banyaknya proposal awal dari setiap kelompok PMMS itu pada pertengan jalan usaha yang dicantumkan dalam proposal mengalami perubahan usaha, sehingga tim monotoring yang ketua oleh Dinas Syari'at Islam Kabupaten Aceh Utara mengalami kesulitan, ditambah lagi keterlambatan kelompok PMMS dalam mengirimkan laporan tahunan yang sudah menjadi kewajiban setiap kelompok untuk ditindaklanjuti oleh tim. (Hasil wawancara dengan Samsul Bahri/ Staf Dinas Syari'at Islam Kab. Aceh Utara, tanggal: 24-02-2012) 
Di samping itu program bantuan PMMS ini yang diberikan dengan cuma-cuma oleh pemerintah tanpa ada ikatan secara hukum, akibatnya dilapangan paket program ini kebanyakan hanya bertahan dua tahun tanpa ada tindak lanjut/perkembangan sebagaimana yang diharapkan sebelumnya yaitu sebagai usaha berantai dalam pengentasan kemiskinan. Kurangnya pelatihan dan pengarahan bagi calon kelompok penerima batuan PMMS juga menjadi kendala bagi mereka dalam meraih manfaat dan sasaran yang ingin dicapai.

Ketika dilakukan monotoring, ternyata didapati bahwa tim monoring yang diketuai oleh Dinas Syari'at Islam tidak berjalan sesuai dengan yang direncanakan/jadwal yang ditentukan untuk turun kelapangan, hal ini disebabkan person yang ditunjuk dari dinas-dinas terkait sering terbentur jadwalnya dengan pekerjaan di dinasnya sendiri sehingga jadwal turun kelapangan sering tertunda-tunda, ditambah lagi masih kurangnya transportasi untuk kelapangan juga sering menjadi kendala, otomatis jarang antara Kelompok PMMS dengan Tim Monotoring semakin jauh, karena jarang bertemu.

Walaupun secara umum program PMMS ini telah mencapai manfaat dan sasaran sebagaimana yang dicanangkan pada awal pelaksanaan program. Ini. Tetapi hendaknya kendala dan hambatan yang dijumpai dilapangan ketika pelaksanaan program PMMS, semestinya segera diatasi dan dibenahi dengan menggunakan terobasan sistem yang lebih baik, demi mencapai visi dan misi dari program ini sendiri, sehingga manfaat dan sasaran yang diinginkan dapat terwujud.

\section{Kesimpulan}

Berdasarkan uraian-uraian pada bagian sebelumnya maka dapat disimpulkan bahwa hasil estimasi model uji t untuk dua sampel yang berpasangan yaitu pendapatan per kepala rata-rata sebelum dan sesudah pelaksanaan program PMMS bagi 10 sampel kelompok PMMS dari 74 kelompok yang ada dan 30 anggota dari 740 orang keseluruhan dalam 12 bulan maka diperoleh kenaikan pendapatan per kepala rata-rata setelah adanya program PMMS 
ini. Dengan kata lain program PMMS ini mampu mengentaskan kemiskinan masyarakat dengan cara meninggikan pendapatan per kepala rata-rata anggota PMMS tersebut. Pelaksanaan program PMMS dilapangan mengalami kendala dan hambatan mulai dari pengrekrutmen anggota kelompok PMMS oleh ketua kelompok yang bernuansa KKN, tidak adanya Tim Teknis dari Dinas terkait seperti, Koperasi, Perternakan dan Pertanian. Tidak adanya ikatan hukum yang membuat program ini berjalan lambat. Semua kendala ini sedikit banyaknya mempengaruhi manfaat dan sasaran program PMMS ini dengan manfaat dan sasaran awalnya.

Secara umum manfaat dan sasaran dari program PMMS ini telah sesuai dengan sasaran dan manfaat awal peluncuran program PMMS ini.

\section{Daftar Pustaka}

BPS., 2012. Kabupaten Aceh Utara dalam Angka 2012.

Dinas Syari'at Islam., 2004. Pedoman Pelaksanaan Syari'at Islam Di Provinsi Nanggroe Aceh Darussalam. Banda Aceh: Dinas Syari'at Islam.

Jhingan, M.L. 2002. Ekonomi Pembangunan dan Perencanaan. Jakarta: Raja Grafindo Persada.

Lewis, O., 1984. Kebudayaan Kemiskinan. dalam Kemiskinan di Perkotaan (Di-edit oleh Parsudi Suparlan). Jakarta: OborSinar Kasih.

Nazir. M., 1988. Metodologi Penelitian. Jakarta: Ghalia Indonesia.

Sukirno, S., 1998. Pengantar Teori Mikroekonomi. Cetakan Kesepuluh. Jakarta: Raja Grafindo Persada.

Santoso, S., 2003. Mengetahuai Berbagai Masalah Statistik dengan BPPS Versi 11,5. Jakarta: Elex Media Komputindo.

Suparlan, P., 1993. Kebudayaan Kemiskinan dan Kehidupan dalam Masyarakat Luas: Pola Pengorganisasian Kehidupan Golongan Miskinan di Perkotaan. Jakarta: Universitas Indonesia.

Tarigan, R. 2002 Perencanaan Pembangunan Wilayah Pendekatan Ekonomi dan Ruang. Medan: USU Press.

Todaro, M.P. 2000 Pembangunan Ekonomi di Dunia Ketiga. Edisi Ketujuh Jilid I. Jakarta: Erlangka. 